Revistade
Economild
Contemporâned

Articles

\title{
COMPETITION POLICY EVALUATION THROUGH DAMAGE ESTIMATION IN FUEL RETAIL CARTEL IN LONDRINA, BRAZIL
}

\author{
Simone Maciel Cuiabano ${ }^{a}$ \\ ${ }^{\mathrm{a}}$ General Coordinator of Public Interest, Secretariat for Foreign Trade, Ministry of the Economy of Brazil. \\ Brasilia, DF, Brazil. ORCID: https://orcid.org/0000-0002-8429-7248.
}

Manuscript received on 2018/03/08 and accepted for publication on 2019/04/09.

\begin{abstract}
This paper estimates the fuel retailer cartel damages in the city of Londrina, Parana, part south of Brazil, using reduced and structural forms for supply and demand. Brazilian Competition Authority (CADE) documents help to characterize the ethanol and gasoline retailers involved in the collusion. The objective is to evaluate competition policy by comparing the amount of estimated damages with the amount of applied fines. This paper also adds an important result to gasoline substitution, as data shows ethanol is perceived as a perfect substitute and its price is inelastic. Results show an overcharge of $3.6 \%$ to $6.6 \%$ in the gasoline market and up to $12 \%$ in the ethanol market during collusion. Fines should consider the deterrence effect and, giving the low probability of detection, CADE's applied fines seemed to be in line with this objective.
\end{abstract}

KEYWORDS: cartel; structural estimation; policy evaluation.

JEL CODES: L41; L71; D43.

Corresponding Author: Simone Cuiabano

E-mail address: scuiabana@gmail.com 


\section{AVALIAÇÃO DE POLÍTICA DE CONCORRÊNCIA: ESTIMAÇÃO DE DANOS NO CARTEL DE POSTOS DE LONDRINA}

RESUMO: Este trabalho estima os danos causados pelo cartel nos postos de gasolina na cidade de Londrina, Paraná, na região sul do Brasil, usando tanto uma equação, quanto um modelo estrutural de demanda e oferta. Documentos do Conselho Administrativo de Defesa Econômica (CADE) ajudam a caracterizar os postos envolvidos na colusão nos mercados de etanol e gasolina. O objetivo é avaliar os efeitos da política de concorrência comparando o montante do dano estimado com as multas aplicadas. Além disso, esse trabalho contribui para a literatura sobre substituição de gasolina, uma vez que os dados apontam que o etanol é percebido como substituto perfeito e tem preço inelástico. Os resultados mostram que houve um sobre custo causado pelo cartel de ordem de 4,6\% a 6,6\% no mercado de gasolina e de até $12 \%$ no mercado de etanol. As multas aplicadas, contudo, devem considerar a probabilidade de o cartel ser descoberto e, dada sua baixa probabilidade, as multas aplicadas no presente caso parecem estar alinhadas com esse objetivo.

PALAVRAS-CHAVE: cartel; estimação estrutural; avaliação de política. 


\section{INTRODUCTION ${ }^{1}$}

Increasingly, Competition Authorities (CA) around the world are quantifying the aggregate benefits of their activities as an impact assessment. In 2016, the Organization for Economic Co-operation and Development (OECD) launched a reference guide on ex-post evaluation of CA' enforcement decisions. Those assessments are of growing interest since they demonstrate the 'value for money' of this public policy. In this article, I estimate the fuel retailer cartel damages in the south region of Brazil to compare with the amount of fines imposed by the Brazilian Competition Authority (CADE). As other jurisdictions, cartels are illegal in the country, being the participants subject to administrative and criminal investigations. ${ }^{2}$ The antitrust law determines that fines may be no less than the amount of harm resulting from the conduct. However, CADE has seldom resorted to this provision when determining fines; when done, the amount imposed was less than the equivalent of the maximum percentage of the defendant's turnover allowed by the law. ${ }^{3}$

Investigation on antitrust violations in the fuel sectors have been a thorn in the side of most CA around the world (OECD, 2013). Although there is an understanding that fuels price volatility can be a result of other factors - i.e. demand or cost shocks, pricing strategies (ex. CLARK and HOUDE, 2013, 2014) - the lack of comprehension from general public may raise doubts on how efficient CA enforce the antitrust law. In the Brazilian experience, the amount of complaints in the fuel retail sector takes almost 1/4 of the workload of CADE. From 2005 to 2010, the institution received an average of 200 complaints per year only in this sector. However, the authority has condemned only 15 unions and fuel retailers' in different municipalities until 2015 because of lack of direct proof (RAGAZZO and DA SILVA, 2006).

This work is related to two strands of literature: demand estimation for ethanol and its substitutability for gasoline, and cartel damage estimation. Anderson (2012)

1 Author would like to thank ANP's Superintendent for Competition Defense and Economic Regulation team and the Department of Economic Studies of CADE for the provision of data and other innumerous support. The views expressed here are those of the author and do not necessarily represent the views of the Ministry of the Economy of Brazil

2 Article 36 of Law 12529/2011 sets forth the basic framework for anticompetitive conduct in Brazil. Criminal cartel investigations are responsibility of the Federal Prosecution Bureau and ruled by the Supreme Court.

3 Antitrust Law determines fines against the companies may range from 0.1 to $20 \%$ of the company's or group of companies' pre-tax turnover in the economic sector affected by the conduct, in the year prior to the beginning of the investigation. This has been used as a rule of thumb by CADE's Tribunal due to the difficulties in harm estimation. 
claims to be the first to provide estimates for ethanol elasticity and argues it is very sensitive to relative prices. This paper contributes to this finding, since cartelists pricing strategy required not only a raise in gasoline price, but also a drop in ethanol price in order to keep relative prices within a margin equivalent to fuel performance and stations distance to the city center. It also innovates with a database from the Brazilian ethanol market, the most consolidated flex fuel vehicles commercialization in the world. ${ }^{4}$

The literature on damage estimation is quite available since private claims started to be implemented both in the US and in Europe. Clark et al. (2004) was the first one to compile a cartel damage quantification study for the EC, giving a structured overview of the court decisions at the time of examination. Connor (2009) examined the antitrust litigation of the lysine cartel rather intensively and points to quantification problems. He emphasizes that the before and after method is rather critical in cases in which cartel formation took place after a recession and under such circumstances the benchmark might be understated and damages overstated, et vice versa. Dijk and Verboven (2007) also distinguish between damage quantification methods that use comparator indicators and methods that are based on direct information about the cartelized market. They also introduce critical loss analysis by determining the breakeven point at which demand decreases, given a particular price increase, and, comparing this to the expected actual loss, cartel price overcharges were calculated.

The discussion about the deterrence effect of cartel fines is also a wide-raging scientific area that is directly related to the actual research. Various studies come to the conclusion that the deterring effects of corporate penalties indeed have been suboptimal during the last years and that competition authorities have to employ detection in addition to deterrence mechanisms (CONNOR, 2009; HÜSCHELRATH and WEIGAND, 2010).

In Brazil, Lucinda and Seixas (2016) published a study on the damages calculation in the cartel of peroxides. She used three different methodologies (time series, difference in differences and a structural model) and observed that damages and fines are very similar in value terms. However, considering the importance of the deterrence effect, either the amount of fines should be raised or the same amount should be claimed by the judiciary as a compensating effect. As this is not yet implemented in the Brazilian system, it should be considered as a public policy instrument.

This work is divided in six parts, including this introduction. In session two, I review the main characteristics of the cartel in Londrina, using information provided in the 4 By 2007, when the cartel was in place, $69 \%$ of the total passenger vehicles in Brazil were flex-fuel (ANFAVEA,
2008). 
condemnation files; session three describes the estimation methodology and presents some descriptive statistics available for the case; session four presents the main estimation results and the results of a general model of price effects in the ethanol and gasoline markets. Session five compares the results of estimated damages with the applied fines. Session six is the conclusion, in which I point out some outcomes that might be useful for future discussion of damage estimation and competition policy evaluation.

\section{THE CARTEL IN LONDRINA AREA}

\subsection{INVESTIGATION AND PROSECUTION}

On the $12^{\text {th }}$ of August of $2007,{ }^{5}$ the Secretariat for Economic Defense (SDE) ${ }^{6}$ opened a cartel investigation after receiving a complaint from the State Policy of Parana informing about a criminal investigation relating fuel retailers in Londrina metropolitan area (cities of Londrina, Cambe, Jataizinho and Ibipora). The State Policy private call interception of the fuel distributor Oil Petro revealed the existence of collusion in the Londrina retail market. On August $29^{\text {th }}$, SDE, SEAE and the Parana policy deflagrated operation 'Medusa III', initiating the execution of search warrants in 16 retailers located in the above mentioned neighbors municipalities. ${ }^{7}$

Phone calls extracts and the questioning documents showed that collusion started when one of the retailers, located in a highway in the municipality of Cambe ('Posto Paizao' or Etiel Comercio de Combustiveis Ltda.), about $15 \mathrm{~km}$ from Londrina center, dropped ethanol price in the beginning of 2007. In response, one of its competitors ('Rede Posto Carajas' or Auto Posto Gasosan Ltda.), located $12.5 \mathrm{~km}$ from the center, also dropped its price, reaching the lowest level of R\$ 0.94 per liter. This 'price war' started to attract drivers used to refuel in retailers located in Londrina city center, whose average price of ethanol ranged from $\mathrm{R} \$ 1.39$ to 1.74 per liter, and average price for gasoline ranged from R\$2.39 to 2.55 per liter. Figure 1 illustrates the geographical

5 CADE convicted 15 cartels involving fuel retailers up to 2015. Most of them related to the price liberalization transition period (1999-2004), but retailers price for that period are not available (BRAZIL, 2014).

6 The competition system in Brazil was composed of three organizations until 2012: the Secretariat of Economic Monitoring (SEAE), attached to the Ministry of Finance, responsible for merger and acquisitions instructions; the Secretariat of Economic Law (SDE), attached to the Ministry of Justice, which instructed cases related to collusion and antitrust violation's complaints; Council of Administrative Economic Defense (CADE), the Court which decided on merger consolidation and antitrust violations condemnations.

7 Process number of reference 08012.0116681/2007-30 (BRAZIL, 2010). 
distribution of the investigated retailers, in red. Green dots mark the presence of family relatives in fuel retail management, which started the talks on the price war. Table 1 describes the linear and drive distances from colluders to the city center.

Figure 1 - Condemned fuel retailers locations

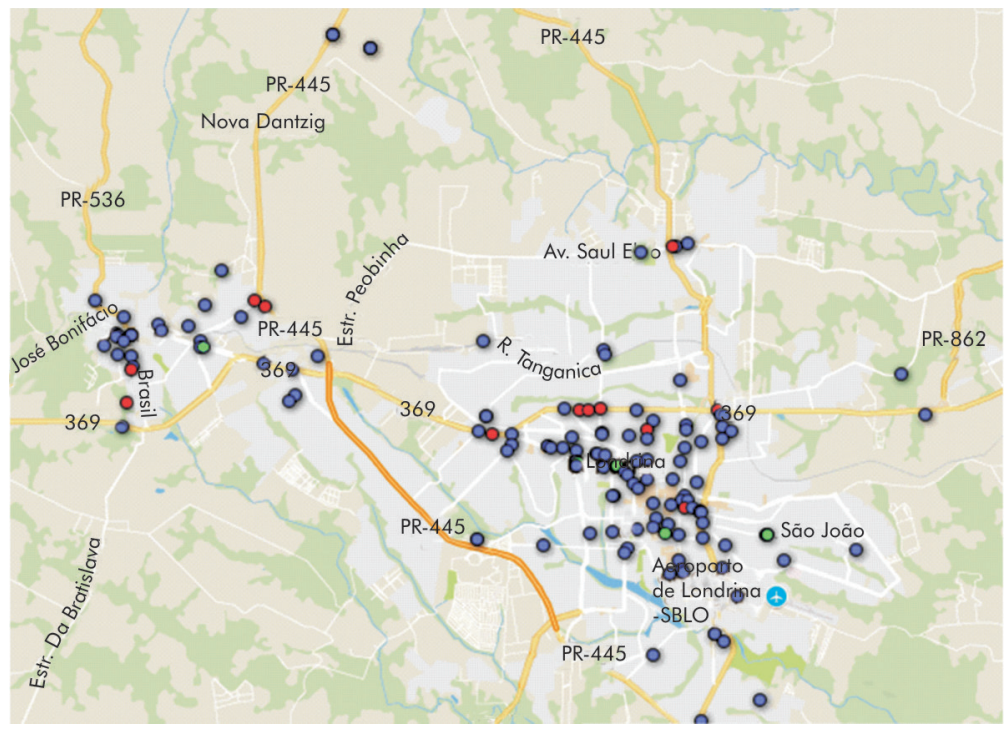

Source: Elaborated with Google Maps.

Table 1 - List of fuel retailers involved in the cartel and distances

\begin{tabular}{lccc}
\hline Retailer & Linear distance $\mathbf{( k m )}$ & Drive distance $\mathbf{( k m )}$ & Drive time (minutes) \\
\hline Auto Posto 10 de Dezembro Ltda. & 1.5 & 2.7 & 7 \\
Kalahan Comercio de Combustiveis Ltda. & 3.4 & 7.1 & 10 \\
Auto PostoExposição Ltda. & 4.6 & 5.1 & 23 \\
$\begin{array}{l}\text { Etiel Comércio de Combustíveis Ltda. } \\
\text { Posto Paizão) }\end{array}$ & 13.9 & 14.9 & 8 \\
$\begin{array}{l}\text { A. A. Fevereiro, Doino e Machado Ltda. } \\
\text { Auto PostoPaiaguás_Ltda. }\end{array}$ & 2.1 & 3.4 & 7 \\
AVN Comercio de combustiveisLtda-Me. & 2.6 & 15.4 & 24 \\
C.O. Bolognesi \& Bolognesi Ltda. (Posto & 13.9 & 2.1 & 5 \\
Tropical) & 1.0 & 11.6 & 19 \\
J Ramalho \& Cia Ltda. (Auto Posto & 10.9 & 1.3 & 5 \\
Versailles III) & 0.5 & 11.6 & 5 \\
Posto Novo Oriente Ltda. & 10.6 & & 5 \\
Auto Posto Portelao Ltda. & & & 5 \\
\hline
\end{tabular}

Source: CADE Administrative Process 08012.011588/2007-30; Google API drive distance based on data for May 2017 from 8:30 am to 13:00 pm. I consider distance from Posto Transamerica, center located, as a benchmark. 
In April/May, 2007, fuel retailer partners located in Londrina center started talking with the owners of the two firms in Cambe to agree on an end of the 'price war', combining the amount of price increases, price fixing ${ }^{8}$ and dates for readjustments. Cartel leaders intervened together with Londrina's retailers, forcing ${ }^{9}$ all associates to agree on price stabilization. Following CADE's documentation, the price uniformization policy did not require a large amount of effort since the condemned retailers were allegedly used as price reference to other fuel retailers in the region.

From the files, I observed that the cartel operated until the end of August 2007, when dawn raids and temporary arrest warrants were carried out. In the threats, fuel retailers decided that a 'fair price' in Cambe would be $\mathrm{R} \$ 1.18$ to ethanol and $\mathrm{R} \$ 2.32$ to gasoline, while in Londrina these prices would be aligned at $\mathrm{R} \$ 1.33$ and $\mathrm{R} \$ 2.43$.

These price differences between ethanol and gasoline are important to explain how apparently distant fuel retailers, i.e., non-competitors, suddenly became fiercely competitors and targets of other retailers. Ethanol is considered to be equal to gasoline when the per-liter price of the first reaches $70 \%$ of the per-liter price of gasoline. Even if gasoline and ethanol are priced about equally in \$ per kilometer traveled, Salvo and Huse (2013) highlight there are consumers' preferences over both fuels, such as consumers' budget constraints (richer consumers prefer gasoline over ethanol), age and environment concerns, that might affect this substitutability.

For instance, one consumer making the choice on gasoline or ethanol, considering only price preferences, facing the lower bound of R $\$ 2.39$ per liter, would compare the profitability of buying ethanol only if its price were lower than $\mathrm{R} \$ 1.68$. However, they would also need to consider if this price was being offered by the same station or in the neighborhood, otherwise they would need to consider transportation costs. Using a vehicle with a performance of $10 \mathrm{~km}$ per liter in gasoline and $7 \mathrm{~km}$ liter in ethanol, the $70 \%$ price difference would justify the choice of a $30 \mathrm{~km}$ round trip to fill up a tank with 40 liters of ethanol - an economy of almost 50\%. In CADE's documents, one retailer owner in the city center confirmed that sales dropped by 300-500 liters a day, not clarifying, however, if these drops are related to gasoline or ethanol.

The cartel operated in two groups, the core one, coordinated by the Guarda family and two other price retailers, was responsible for determining and price monitoring. This involved the participation of a fuel distributor, Oil Petro, whose commercial manager, Mauro Guarda, kept vertical relations with one fuel retailer of the same

8 The agreement went up to the $2^{\text {nd }}$ decimal level price combination in which some retailers could raise or drop their prices up to $\mathrm{R} \$ 0.03$, adjusting it to demand changes.

9 The pressure involved physical threatening, verbal abuse and harassment of retailers. 
name. The second group involved main fuel retailers in the cities of Londrina and Cambe, which were considered price makers because of their commercialized size. CADE'S documents show that these retailers accepted to participate in the agreement by changing their price in the date suggested by the core group, influencing the rest of fuel retailers to follow the leaders.

Apart from penal prosecution, CADE deliberated on penalties which summed up more R\$ 10 million (US\$ 5 million), described in the Appendix. The amount of fines was ruled based on art. 37 and 45 of the National Antitrust Law 12529/2011, which can range from $0.1 \%$ to $20 \%$ from the total firm revenue. According to the Commissioner's (FRAZAO, 2013, Decision in the Process 08012.011668/2007-30, v. 8), her decision of fixing a $13 \%-15 \%$ rate was based on the direct and indirect participation of the defendants. Although the law explicitly affirms that imposed fines should not be lesser than illegal profits, estimation difficulties impede CADE to proceed with this ruling more frequently.

\section{ESTIMATION STRATEGY}

\subsection{METHODOLOGY}

In order to define the illegal profits and the damages of the cartel, I used CADE'S information to define its duration, from May to August 2007. Quantifying damages involves estimating the price that would have occurred in the absence of the cartel during the estimated period. For that, I need to characterize the market conditions for ethanol and gasoline demand in Londrina.

I start with a standard oligopoly model of competition that incorporates price discrimination over fuels and stations characteristics. As from obtained in cartel documents, retailers set they prices differently from which other, based on location and demand flow. These characteristics were observed even during the cartel period when they set prices differences up to the third decimal level. Considering that retailers operate in ethanol and gasoline, the individual firm profit function is:

$$
\pi^{j}=\left(p_{g}-w_{g}-c_{g}\right) s_{g}+\left(p_{e}-w_{e}-c_{e}\right) s_{e}
$$

In (1), $p_{g}, p_{e}$ are the respective prices for gasoline and ethanol, $w_{g}, w_{e}$ are their respective wholesale paid price, and $c_{g}, c_{e}$ is the retailer's constant marginal cost of distribution for each fuel. Fuels specific market shares are given by $s_{g}, s_{e}$. Cost shifters are such as the wholesale price, distance to city center, number of pumps and tankage size. 
Assuming the existence of pure-strategy Bertrand-Nash equilibrium, the price for each fuel must satisfy the following first order conditions:

$$
\begin{gathered}
s_{g}+\left(p_{g}-w_{g}-c_{g}\right) \frac{\partial s_{g}}{\partial p_{g}}=0 \\
s_{e}+\left(p_{e}-w_{e}-c_{e}\right) \frac{\partial s_{e}}{\partial p_{e}}=0
\end{gathered}
$$

Equations (2) and (3) imply that the vector of retailer's margins is the retail price minus the wholesale price minus the marginal cost of distribution:

$$
\gamma=p-w-c
$$

Price-cost margins estimations require the observation of the demand shape to infer firm's margins. Anderson (2012) develops a model of demand for ethanol as a gasoline substitute, in which the household will choose the fuel with the lower ethanolequivalent price. Aggregate demand for both gasoline and ethanol will be a smooth function of relative prices when fuel-switching price ratios are distributed continuously. The log-linear aggregated demand equations for gasoline and ethanol are therefore:

$$
\begin{aligned}
& \ln Q_{\text {git }}=\propto_{g}+\beta_{0} \ln \text { cars }_{t}-\beta_{1} \ln p_{\text {git }}+\beta_{2} \ln p_{\text {eit }}-\beta^{d} \ln \text { timetravel }_{i n}+\varepsilon_{i j} \\
& \ln Q_{\text {eit }}=\propto_{e}+\beta_{3} \ln \text { cars }_{t}-\beta_{4} \ln p_{\text {eit }}+\beta_{2} \ln p_{\text {git }}-\beta^{d} \ln \text { timetravel }_{i n}+\varepsilon_{i j}
\end{aligned}
$$

In (5) and (6), $Q_{\text {git }}, \ln Q_{\text {eit }}$ are both quantities of gasoline and ethanol sold by each station $i$ in time $t, p_{g j} p_{e j}$ are the retailers price for gasoline and ethanol, timetravel ${ }^{10}$ captures the travel time period between $i$ and $n$, the cartel leader in city center, $\varepsilon$ is an index of unobserved station attributes. I will test whether travel distance from the city center to retailers located elsewhere may affect demand preferences as pointed out by Houde (2012).

Reduced form demand estimation equations for gasoline and ethanol prices in a panel for $i$ retailers in time $t$ are such as:

$$
\begin{aligned}
& P_{g i t}=\propto_{0}+\beta_{1} P_{\text {eit }}+\beta_{2} \text { timetravel }_{j n}+\beta_{3} w_{g}+\beta_{4} c_{g}+\epsilon_{i j} \\
& P_{e j t}=\propto_{5}+\beta_{6} P_{g i t}+\beta_{7} \text { timetravel }_{j n}+\beta_{8} w_{e}+\beta_{9} c_{e}+\epsilon_{i j}
\end{aligned}
$$

${ }^{10}$ Data collect on May 13, 2017 from 8:30am to 2pm, local time of Londrina. 
In (7) and (8), w are costs related to the wholesale distributors and to other cost shifters, such as information on tankage size and if the retailer is unbranded. Once estimated parameters for each fuel I can include a dummy for the firms involved in the cartel during that specific time and use a linear estimator with random effects, such as:

$$
\begin{aligned}
& P_{g i t}=\propto_{0}+\beta_{1} P_{\text {eit }}+\beta_{2} \text { timetravel }_{j n}+\beta_{3} w_{g}+\beta_{4} c_{g}+\varphi_{\text {eta }} d_{\text {cartelIDg }}+\epsilon_{i j} \\
& P_{\text {ejt }}=\propto_{5}+\beta_{6} P_{\text {git }}+\beta_{7} \text { timetravel }_{j n}+\beta_{8} w_{e}+\beta_{9} c_{e}+\varphi_{\text {gas }} d_{\text {cartelIDe }}+\epsilon_{i j}
\end{aligned}
$$

For the structural model, I estimate equations (5) and (6) using cost information such as the wholesale prices and tankage as instruments. I also include the average price for the $1 \mathrm{~km}$ competitors' on gasoline and ethanol to control for price changes not related to the sold quantity. With the estimated elasticities, I can simulate the 'but for price' for each retailer considering its individual mark-up rules and wholesale costs.

\subsection{DATABASE AND STATISTICS}

I used the information in the file process to characterize cartelists and the cartel period. In addition, I aggregated three databases with information regarding fuel retailers in Londrina and Cambe ${ }^{11}$ obtained from the Brazilian Fuel Regulator (Agência Nacional do Petróleo, Gás Natural e Biocombustíveis - ANP): (i) an unbalanced weekly panel of retailers and wholesale prices for diesel, gasoline and ethanol from 2007 to 2009, including brand characteristics and georeferenced locations; (ii) a monthly panel of retailers acquired quantities of diesel, gasoline and ethanol also spanning from 2007 to 2009; (iii) a cross section of retailers characteristics such as numbers of pumps and tankage. Since this last makes reference to retailers in 2014, I also cross checked for information in ANP website ${ }^{12}$ regarding retailers which are no longer in operation, but whose characteristics are still available.

I obtained travel and time distances using Google API for each station regarding one fuel retailer located at the city center, but not mentioned in the files. ${ }^{13} \mathrm{I}$ also added information regarding regional inflation rate for the period and control variables, such

\footnotetext{
11 ANP price collection methodology does not include Ibipora or Jataizinho, due to its sample size. Price and quantity information for each gas station are not available in the disclosured process files.

12 Available at: <http://www.anp.gov.br/postos/consulta.asp >.

13 Posto Transamerica, CNPJ 07.775.477/0001-98.
} 
as total number of passenger's cars. The sample includes prices and quantities for the sale of gasoline, ethanol and diesel in 154 fuel retailers in Londrina for a period of 36 months (three years), totalizing 5,544 observations. Considering missing price data, however, I have only 443 completed information for gasoline and 440 completed information for ethanol.

For inflation, I consider the State of Parana index for Consumer Price (IPCA) provided by the Brazilian Institute of Statistics (IBGE). Other general price cost shifters, such as the international sugar price and petrol were obtained through the International Monetary Fund (IMF) statistics. The Parana State Department for Traffic Control (Detran/PR) provided Licensed vehicles in the city of Londrina and Cambe.

Tables 2 and 3 summarize the key variables. On average, fuel retailers in Londrina sold about 75,000 liters of gasoline, 50,000 liters of ethanol and 76,000 of diesel per month. However, these volumes changed along the years, remarked in 2009 when there was a $20 \%$ rise in the commercialization of ethanol and $18 \%$ of diesel compared to 2007.

Table 2 - Summary Statistics on Volumes

\begin{tabular}{lcccccccccccccc}
\hline & \multicolumn{3}{c}{ Overall } & \multicolumn{1}{c}{ 2007 } & \multicolumn{3}{c}{ 2008 } & & \multicolumn{2}{c}{$\mathbf{2 0 0 9}$} \\
$\begin{array}{l}\text { Quantities } \\
\text { (liter/month) }\end{array}$ & Mean & SD & $\#$ & Mean & SD & $\#$ & Mean & SD & $\#$ & Mean & SD & $\#$ \\
\hline Gasoline & 74,914 & 54,056 & 157 & 76,680 & 51,187 & 127 & 74,914 & 54,056 & 157 & 68,599 & 53,176 & 130 \\
Ethanol & 49,790 & 45,410 & 160 & 33,246 & 29,923 & 132 & 49,790 & 45,410 & 160 & 56,655 & 50,565 & 131 \\
Diesel & 76,271 & 13,3078 & 154 & 71,456 & 15,108 & 118 & 76,271 & 13,307 & 154 & 89,905 & 12,996 & 130 \\
\hline
\end{tabular}

Source: own calculations

The summary quantities statistics also highlight the amount of heterogeneity across stations in Londrina between 2007 and 2009. Gasoline had the highest standard deviations compared to the commercialization of diesel, for instance. But the commercialization of ethanol got increasingly dispersed along the years - standard deviation went from 30,000 liters in 2007 to 50,500 liters in 2009.

This heterogeneity is also caught by characteristics such as number of pumps and tanks. Overall, stations have more variation regarding the number of gasoline pumps and less for diesel, despite these last vary more in terms of tankage. Stations prosecuted for collusion, however, had more similar characteristics in terms of number of pumps of gasoline and ethanol, corroborating the information available in CADE'S files regarding the collusion in these two markets. On average, cartelists had three gasoline pumps and three ethanol pumps, while stores outside the cartel had six pumps for gasoline and four for ethanol. However, they had more pumps for diesel, reflecting the agreement choice for retailers located in the highway and used to have more clients for diesel. Stores in the cartel were also slightly geographically more spread in the same comparison as shown in Table 3 . 
Table 3 - Summary Statistics on Prices and Characteristics

\begin{tabular}{|c|c|c|c|c|c|c|}
\hline & Overall & & & Not in collusion & & \\
\hline & Mean & SD & Mean & SD & Mean & SD \\
\hline $\begin{array}{l}\text { Gasoline price }(\mathrm{R} \$ / \\
\mathrm{Lt})\end{array}$ & 2.451 & 0.099 & 2.370 & 0.071 & 2.451 & 0.099 \\
\hline $\begin{array}{l}\text { Ethanolprice (R\$/ } \\
\mathrm{Lt})\end{array}$ & 1.466 & 0.206 & 1.192 & 0.122 & 1.468 & 0.205 \\
\hline Diesel price $(\mathrm{R} \$ / \mathrm{Lt})$ & 1.914 & 0.088 & 1.767 & 0.041 & 1.916 & 0.087 \\
\hline Pumps gas & 5.047 & 3.056 & 3.857 & 2.762 & 5.055 & 3.057 \\
\hline Pumps ethanol & 3.506 & 1.938 & 3.000 & 1.342 & 3.509 & 1.941 \\
\hline Pumps diesel & 2.659 & 2.156 & 3.571 & 2.891 & 2.653 & 2.150 \\
\hline $\begin{array}{l}\text { Tanks gasoline } \\
\text { (liter) }\end{array}$ & 32.118 & 12.473 & 25.000 & 10.607 & 32.167 & 12.472 \\
\hline $\begin{array}{l}\text { Tanks ethanol } \\
\text { (liter) }\end{array}$ & 22.412 & 10.783 & 19.286 & 6.944 & 22.433 & 10.803 \\
\hline Tanks diesel (liter) & 24.529 & 20.463 & 28.571 & 13.887 & 24.501 & 20.500 \\
\hline Distance $(\mathrm{Km})$ & 5.538 & 5.233 & 6.455 & 4.977 & 5.532 & 5.235 \\
\hline $\begin{array}{l}\text { Drive distance } \\
\text { (minutes) }\end{array}$ & 10.859 & 6.591 & 11.636 & 6.823 & 10.854 & 6.590 \\
\hline
\end{tabular}

Source: own calculations.

In terms of price, the overall price per liter for gasoline was R\$ 2.45 (US\$ 1.22) with a dispersion of 0.09 cents. During the cartel, colluding firms presented lower average gasoline price than non-colluding ones ( 0.08 cents difference); nevertheless, colluders presented lower dispersion. Similar patterns can be seen for ethanol and diesel prices: despite cartelists, ethanol and diesel prices were about $R$ \$ 0.27 and $R \$$ 0.15 lower than non-cartelists, their variation across stations was much lower. The fact that these fuel stations were located far from the city center explains the lower average price. In addition, as documented in the files, cartelists have greater tankage in diesel, being an important part of total revenue.

One of the most important changes in the operations of the fuels market in Brazil concerns its business model. Until 1997, service stations were necessarily tied to distributors and carried their brands, acting in the market as franchise units. Thus, transactions between distributors and service stations occurred through loyalty contracts and negotiation exclusivity. Since deregulation, a new model has allowed the establishment of stations without supply contracts with a distributor. These are dubbed 'unbranded' or 'white flag' service stations, insofar as they are not franchises of any distributors. Most retailers in Londrina region declared themselves as white flags, as Table 5 shows. Retailers involved in the cartel were a majority of unbranded retailers 
(54\%), which also helps to understand the lower price differences and the role of Oil Petrol, the regional distributor, as one of the leaders of the cartel.

\section{ESTIMATION RESULTS}

\subsection{GASOLINE}

As the cartel period and colluding firms are already known, reduced form estimations can help to give a glimpse on how much price were affected. Gasoline and ethanol prices are explained by costs and demand shifters such as distance (time to travel from the city center of Londrina to each retailer, including those in Cambe), if the store is not branded, tankage and number of pumps. I did not consider costs related to the commercialization of other fuels because $90 \%$ of the total stations traded both of them.

For gasoline, I tested different specifications in which the most robust includes retailer price information for ethanol. This is not a novelty in the Brazilian market because of fuels substitutability. Ethanol retailer price's ('PRECOVENDAETANOLd') augmentation in 1 Real would cause an average rise of 0.089 cents in gasoline retailer's price. ${ }^{14}$

Time to travel ('time') and travel distance to travel ('dist') seemed to be correlated, so I dropped one of them in the final specification. Travel distance from the city center presented the negative expected signs, though the magnitude of the impact was not very high: for each kilometer, there was a drop lower than one cent of Real. Here, I needed more information on commuting choices to better observe consumer's choice.

Acquisition price from distributors ('PRECOCOMPRAGASd') represented the highest and most straightforward impacts on retailer's prices: 1 Real of price increase from distributors had a direct pass-through effect over retailer's prices, ranging from 1.04 to 1.05 price augmentation at the pump. On the other hand, the choice of being an unbranded store ('d_branca') did not seem to have much impact on retailers' prices, which might indicate that a tacit collusion behavior was already in place in both municipalities. Storage capacity ('tanks_gas') is correlated with lower prices, as it was expected from literature. These effects, however, were strikingly lower compared to the positive coefficients of price increase, which might reflect managers' capacity to avoid extra costs. ${ }^{14}$ Nearly $50 \%$ of the vehicles in the State of Parana had the flex-fuel technology already in place (MINISTRY
OF ENVIRONMENT, 2011, p. 90, graph 70). 
During the cartel, the price of the firms involved in collusion was 0.13 cents higher than other periods, including before and after the cartel. I cannot assume this as a direct effect of the cartel, though, since there are also effects associated with the cross price elasticity for the ethanol consumption.

Table 4 - Reduced Price Demand Regressions for Gasoline

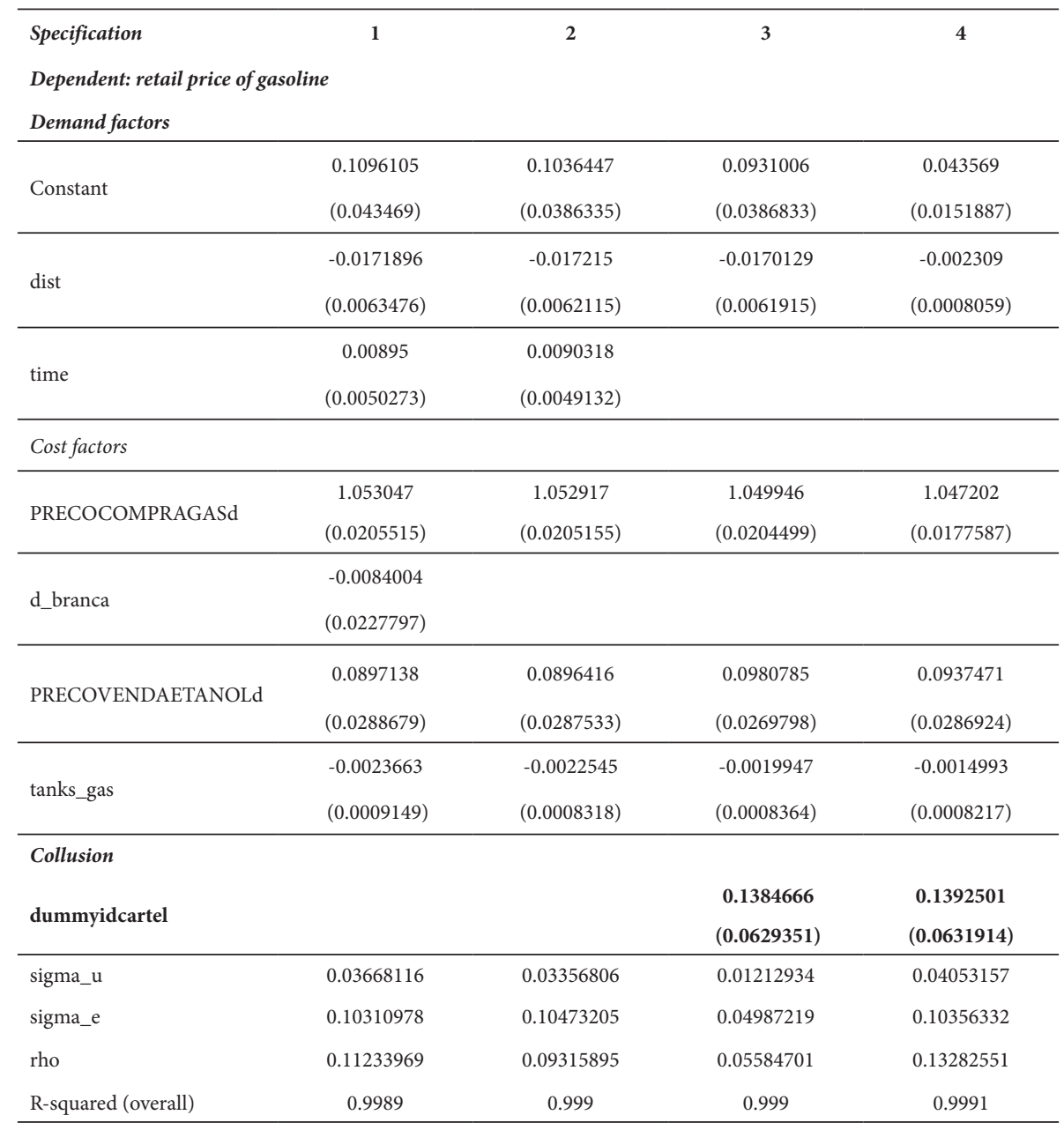

Notes: Standard errors in (). 164 observations per estimation. Results at specifications 3 and 4 are significant at $1 \%$. Source: own calculations.

For the structural demand estimation, I regressed equation (5) using the information on wholesale costs per retailer, the size of tankage and the average price of neighboring retailers in a $1 \mathrm{~km}$ ray as instruments. Price effects on quantities have the expected signs and it confirms the low price elasticity for gasoline in the region: a 1\% 
price raise drops the demanded quantity in less than $0.6 \%$. The effect of a price raise in ethanol increases the demand for gasoline also around $0.6 \%{ }^{15}$

Table 5 - Demand Estimation for Gasoline

\begin{tabular}{lccc}
\hline Specification & $\mathbf{1}$ & $\mathbf{2}$ & $\mathbf{3}$ \\
Dependent: logarithm of gasoline quantity & 25.55381 & & \\
\hline cons & $(6.698227)$ & 26.94924 & $(6.840229)$ \\
\hline lprecovendagas & -0.4547253 & $(6.828287)$ & -0.5734533 \\
\hline lprecovendaetanol & $(0.3077597)$ & -0.5590767 & $(0.3066743)$ \\
\hline & 0.5183416 & $(0.3060727)$ & 0.6123401 \\
lcars & $(0.2816827)$ & 0.5999931 & $(0.2793655)$ \\
\hline ltime & -1.182731 & $(0.2788484)$ & -1.303361 \\
\hline sigma_u & $(0.5447383)$ & -1.291657 & $(0.5559122)$ \\
sigma_e & & $(0.5551726)$ & 0.1144555 \\
rho & & & $(0.1375862)$ \\
\hline
\end{tabular}

Note: Standard errors in ().1. Instruments: Ipm_conc_1 km Iprecocompragas; 2. Ipm_conc_1 km Iprecocompragasltanksg; 3. lpm_conc_1 km Iprecocompragasltanksg.

Source: own calculations.

Overcharges can be calculated supposing the "but for price" is a result of a monopolistic competition in which retailers add a markup rule to wholesale costs, given its share:

$$
p_{i t}^{\text {butprice }}=\text { costs }_{\text {git }}+\left(-\frac{s}{\varepsilon}\right)
$$

Overcharges in the structural model are also positive and significant, $\mathrm{R} \$ 0.38$ cents higher in average (9.8\% overcharge, against $4.7 \%$ overcharge in the reduced form). Figure 2 compares both estimated, but for prices with the actual price charged by retailers.

${ }^{15}$ Levin, Lewis and Wolak found lower elasticities in the US estimating demand using higher levels of spatial and temporal aggregation. 
Figure 2 - Gasoline actual sold prices and estimated competing prices

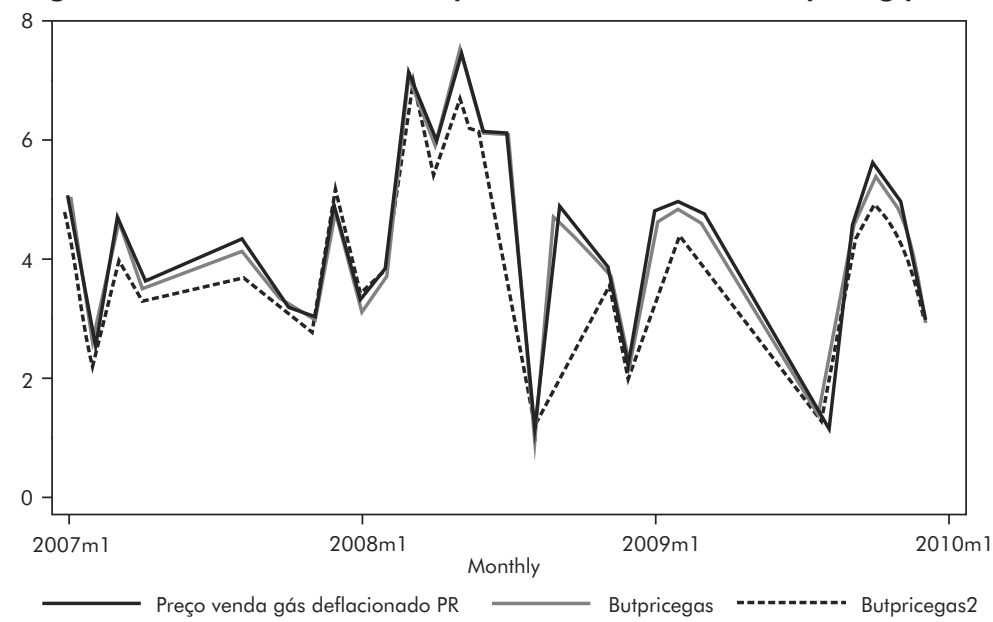

Source: own calculations.

\subsection{ETHANOL}

In the ethanol price specifications, I included both the same demand variables as in gasoline ('dist' and 'time'). For cost shifters, I also included the acquisition price of ethanol from distributors ('PRECOCOMPRAETANOLd') as well as the gasoline substitute effects ('PRECOVENDAGASd'). The main difference is the inclusion of the index of the international sugar price ('sugar') to the analysis, since the same cane is used for sugar or ethanol production. In Brazil, producers have a flexibility to switch between sugar and ethanol and the use of cane was about 50\% to 50\% until 2006. From then, industry growth switched to ethanol due to an increasing number of FFV vehicles and an increased demand for fuel ethanol. However, producer's decisions on the supply of ethanol are highly dependent on the future prospective price for sugar. For instance, sugar mix was maximized in 2011 and 2012 due to high global sugar prices, leading to a lower supply of ethanol (COVRIG, 2014).

The impact of sugar prices on retailers' was positive and significant in specifications 3 and 4 . Although in specification 1 the sign was negative, this one did include extra variables that I dropped in other regressions due to lower explanatory power, such as time and distance. As in the gasoline regressions, travel distance had a negative effect on ethanol's price, but with the same low magnitude impact.

Information on the unbranded store ('d_branca') also did not bring information on prices, so I dropped in the last specifications, as well as the information on the number of ethanol pumps ('bicos_eta'). 
Acquisition price from distributors ('PRECOCOMPRAETANOLd') also did seem to have a direct effect on retailers' prices, though in a much smaller magnitude than gasoline costs pass-through. This might be a reflex of consumers' preferences for the later and firms' ability to absorb some of the costs in order to avoid excessive stocks for the product. Gasoline retail price augmentation ('PRECOVENDAGASd'), on the other hand, had a higher pass-through on ethanol's price than the effect of the ethanol price on gasoline. This shows that retailers pricing strategies consider not only costs, but also demand preferences and substitution. A higher gasoline retail price allows firms to raise more ethanol's price than the opposite, respecting the fuel efficiency thumb rule of $70 \%$ of ethanol/gasoline.

Table 6 - Reduced Price Demand Regressions for Ethanol

\begin{tabular}{|c|c|c|c|c|}
\hline \multicolumn{5}{|c|}{$\begin{array}{l}\text { Dependent: retail price of ethanol } \\
\text { Demand factors }\end{array}$} \\
\hline _cons & $\begin{array}{r}0.2293977 \\
(0.1088252) \\
\end{array}$ & $\begin{array}{l}-0.6820153 \\
(0.1000504) \\
\end{array}$ & $\begin{array}{l}-0.7618369 \\
(0.0948181) \\
\end{array}$ & $\begin{array}{l}-0.7903439 \\
(0.0952531) \\
\end{array}$ \\
\hline dist & $\begin{array}{l}0.0030712 \\
(0.0134118)\end{array}$ & $\begin{array}{c}0.0105773 \\
(0.0080061)\end{array}$ & & $\begin{array}{l}-0.0050015 \\
(0.0023574)\end{array}$ \\
\hline time & $\begin{array}{l}-0.0052832 \\
(0.0110065)\end{array}$ & $\begin{array}{l}-0.013321 \\
(0.006522) \\
\end{array}$ & $\begin{array}{l}-0.0053529 \\
(0.0018683)\end{array}$ & \\
\hline Costfactors & & & & \\
\hline PRECOCOMPRAETANOLd & $\begin{array}{c}1.161412 \\
(0.0207021) \\
\end{array}$ & $\begin{array}{r}0.4200158 \\
(0.0603231) \\
\end{array}$ & $\begin{array}{l}0.3800242 \\
(0.0548631)\end{array}$ & $\begin{array}{r}0.3804374 \\
(0.0564332) \\
\end{array}$ \\
\hline d_branca & $\begin{array}{c}0.1917472 \\
(0.0469142)\end{array}$ & $\begin{array}{c}0.048704 \\
(0.0323915)\end{array}$ & & \\
\hline PRECOVENDAGASd & & $\begin{array}{c}0.4033752 \\
(0.0317775)\end{array}$ & $\begin{array}{c}0.4252455 \\
(0.0290005)\end{array}$ & $\begin{array}{c}0.4249725 \\
(0.0298097)\end{array}$ \\
\hline tank_eta & $\begin{array}{l}-0.0032696 \\
(0.0020202)\end{array}$ & $\begin{array}{l}-0.0022551 \\
(0.001217)\end{array}$ & $\begin{array}{l}-0.002262 \\
(0.0011911)\end{array}$ & $\begin{array}{l}-0.0025557 \\
(0.0012002)\end{array}$ \\
\hline sugar & $\begin{array}{l}-0.0049045 \\
0.0066979\end{array}$ & $\begin{array}{l}0.0535773 \\
0.0064634\end{array}$ & $\begin{array}{l}0.0575578 \\
0.0059689\end{array}$ & $\begin{array}{l}0.0578314 \\
0.0060654\end{array}$ \\
\hline Collusion & & & & \\
\hline dummyidcartel & & & & $\begin{array}{l}-0.0382886 \\
(0.1550836)\end{array}$ \\
\hline sigma_u & 0.08968003 & 0.00690577 & 0 & 0 \\
\hline sigma_e & 0.18962417 & 0.13691181 & 0.14413066 & 0.14483054 \\
\hline rho & 0.18278497 & 0.00253769 & 0 & 0 \\
\hline R-squared (overall) & 0.9846 & 0.9899 & 0.9932 & 0.9932 \\
\hline
\end{tabular}

Notes: Standard errors in (). Results are significant at $1 \%$.

Source: own calculations. 
During collusion, ethanol prices were 0.038 cents lower than prices out of that period. Although this might seem controversial, it may reflect firms pricing strategy to keep gasoline and ethanol prices balanced and to keep a stable revenue for colluders. Remembering that the cartel started after a 'price war' in the ethanol market, in which the revenue of competitors firms was lowering because of consumers' gasoline substitution. By lowering ethanol prices to a certain level, cartelists kept the amount of gasoline and ethanol sales.

Price elasticity for ethanol was quite similar to the one obtained for gasoline, showing that the products are perceived as substitutes $(-0.57$ and -0.55$)$. In both gasoline and ethanol estimations, travel distance was associated with a positive effect on quantities. Since I do not have information on commuters, it is inconclusive whether there is larger demand for retailers located outside of the city center, as it might indicate.

Table 7 - Demand Estimation for Ethanol

\begin{tabular}{lccc}
\hline Specification & $\mathbf{1}$ & $\mathbf{2}$ & $\mathbf{3}$ \\
Dependent: logarithm of ethanol quantity & -40.45567 & & -40.73871 \\
\hline cons & $(13.92972)$ & -43.16309 & $(13.93184)$ \\
\hline lprecovendagas & 0.6206255 & $(17.50656)$ & 0.6165984 \\
\hline lprecovendaetanol & $(0.6998246)$ & 1.105276 & $(0.7000006)$ \\
\hline lcars & -0.5546346 & $(0.8535769)$ & -0.5548431 \\
& $(0.6414875)$ & -1.022595 & $(0.6415611)$ \\
\hline ltime & 4.206299 & $(0.7785791)$ & 4.205395 \\
\hline sigma_u & $(1.129817)$ & 4.40747 & $(1.129979)$ \\
sigma_e & & $(1.419404)$ & 0.1383563 \\
rho & & & $(0.1556563)$ \\
\hline
\end{tabular}

Note: Standard errors in ().1. Instruments: Ipm_conc_1 km Iprecocompragas; 2. Ipm_conc_1 km Iprecocompragasltanksg; 3. Ipm_conc_1 km Iprecocompragasltanksg.

Source: own calculations.

Using the structural demand, calculated overcharges were of R\$ 0.38 cents for ethanol (16\% over estimated prices), against the price reduction observed in the reduced form. This impacts damages estimation and fines calibration, as I show in the next session. 
Figure 3 - Ethanol actual sold prices and estimated competing prices

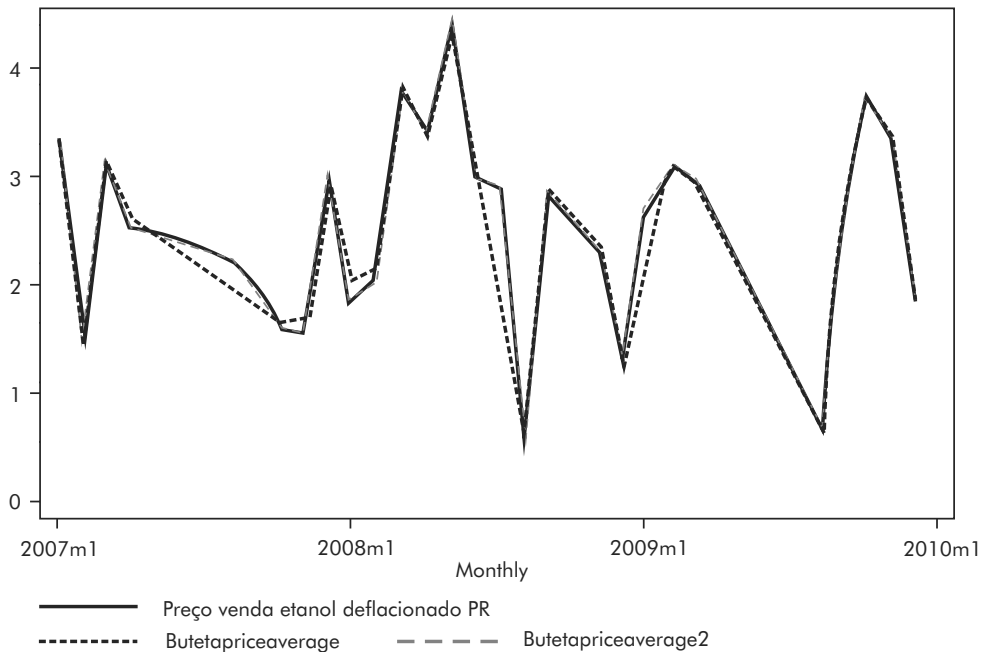

Source: own calculations

\section{EVALUATING COMPETITION POLICY: FINES VS ESTIMATED DAMAGES}

In order to calculate estimated damages with the results from the reduced and structural approaches, I must consider the net cross effects of the coefficients of both gasoline and ethanol retailers' price in each other. For instance, one Real increase in ethanol price was related to $\mathrm{R} \$ 0.0937471$ cents rise in the gasoline price. Considering the hypothesis that colluders dropped ethanol price by -0.0382886 , keeping the same proportionality, it is equivalent to assume that the net gasoline price augmentation was of $\mathrm{R} \$ 0.135$. For ethanol, it was about $\mathrm{R} \$ 0.02$.

Worth to say that price overcharges were in line with the observed in refereed literature, such as in Connor and Bolotova (2006). There are studies about overcharge proportion being related to oligopolistic environments and higher barriers to entry. ${ }^{16}$ As fuel retail is neither one of them, lower cartel overcharge is expected. This finding also reflects colluder's preoccupation in setting the 'right' price for which retailer considering differences up to the third decimal level. ${ }^{17}$

16 Bolotova et al. (2008) have a nice overcharge/industry characteristic correlation analysis.

${ }^{17}$ In one of the dialogues between Djalma Guarda Junior and Djalma Guarda, both son and father, the first insists to correct that agreed ethanol price was 1.269 , not 1.259, as the father believed. 
Table 8 - Overcharges estimations in the reduced form (in R\$)

\begin{tabular}{lcccccc}
\hline & $\begin{array}{c}\text { Cartel Overcharge } \\
\text { ("dummyidcartel") }\end{array}$ & $\begin{array}{c}\text { Cross price } \\
\text { coefficients }\end{array}$ & Priceeffect & Net effect & $\begin{array}{c}\text { But for prices } \\
\text { (average) }\end{array}$ & $\begin{array}{c}\text { Net } \\
\text { Overcharge }\end{array}$ \\
\hline Gasoline & 0.139 & 0.093 & -0.003 & 0.135 & 3.798 & $3.60 \%$ \\
Ethanol & -0.038 & 0.424 & 0.059 & 0.020 & 2.430 & $0.86 \%$ \\
\hline
\end{tabular}

Source: own calculations.

Table 9 - Overcharges estimations using Structural form (in R\$)

\begin{tabular}{lccccc}
\hline & $\begin{array}{c}\text { Cartel } \\
\text { excessive } \\
\text { price } \\
\text { Without cross } \\
\text { effects }\end{array}$ & $\begin{array}{c}\text { Overcharges } \\
\text { Without cross } \\
\text { effects }\end{array}$ & $\begin{array}{c}\text { But for prices } \\
\text { Without cross } \\
\text { effects }\end{array}$ & $\begin{array}{c}\text { But for prices } \\
\text { (average) }\end{array}$ & $\begin{array}{c}\text { Net } \\
\text { Overcharge }\end{array}$ \\
\hline Gasoline & 0.389 & $9.849 \%$ & 3.537 & 3.658 & $6.68 \%$ \\
Ethanol & 0.382 & $16.325 \%$ & 1.957 & 2.028 & $12.5 \%$ \\
\hline
\end{tabular}

Source: own calculations.

To calculate the damages, one must consider the total quantity sold by each firm at the period; however, this information is not available for all the firms in collusion, which might lead to underestimated effect. Considering that involved retailers were also price leaders, regulating prices setting in the city, I estimate damages considering the total volume sold both in the gasoline and ethanol markets during the cartel period. Table 10 shows calculated damages considering reduced and structural estimations and its cross effects. Results from the last form show a higher damage than the reduced form. Total amount of damages were not very high especially because of the low duration of the cartel (three months).

Table 10 - Damages estimations (in R\$)

\begin{tabular}{lcccc}
\hline & Reduced form & Structural form & $\begin{array}{c}\text { With cross-effects } \\
(\mathbf{R})\end{array}$ & $\begin{array}{c}\text { With cross-effects } \\
(\mathbf{E})\end{array}$ \\
\hline Gasoline & $134,515.8$ & 457,936 & $131,048.3$ & $295,352.8$ \\
Ethanol & $-10,644.23$ & $117,001.2$ & $-15,167.73$ & $92,648.25$ \\
Total & $\mathbf{1 2 3 , 8 7 1 . 5 7}$ & $\mathbf{5 7 4 , 9 3 7 . 2 0}$ & $\mathbf{1 1 5 , 8 8 0 . 5 7}$ & $\mathbf{3 8 8 , 0 0 1 . 0 5}$ \\
\hline
\end{tabular}

Source: own calculations.

The amount of CADE'S fine summed up $\mathrm{R} \$ 10,964,962.2$. This is 20 times higher than the highest estimated damages. Optimal deterrence theory claims that fines should be inversely proportional to the probability of being discovered in crime. If firms 
exclusively think about collusion as an economic decision to increase profits and refrain from ethical principles, the question to be answered is whether the gain from price fixing outweighs expected punishments. The probability of detection is very difficult to assess, although some studies tried that. The research of Allain et al (2013) reviews the main papers that tried to assess these probabilities, ranging from $10 \%$ to $33 \%$, consistent with the probability of detection for other crimes. Using this information to evaluate applied fines, I observe that Cade's policy choice in the case seemed to be higher with the expected deterrence effect, considering damages, dawn raid costs and the probability of being caught. However, CADE'S policy reflected a deterrence effect of $5 \%$, which may be considered a more realistic to the authority's capacity of cartel detection, given the proportionality of the authority to the country dimensions.

Table 11 - Fines (punishment) considering the probability of detection

\begin{tabular}{lcccc}
\hline $\begin{array}{l}\text { Probability of being } \\
\text { caught }\end{array}$ & Penalty1 & Penalty2 & Penalty3 & Penalty4 \\
\hline $\mathbf{0 . 0 5}$ & $\mathbf{2 4 7 7 \mathbf { 4 3 1 . 4 0 }}$ & $\mathbf{1 1 4 9 8 7 4 4 . 0 0}$ & $\mathbf{2 3 1 7 6 1 1 . 4 0}$ & $\mathbf{7 7 6 0 0 2 1 . 0 0}$ \\
0.1 & 1238715.70 & 5749372.00 & 1158805.70 & 3880010.50 \\
0.15 & 825810.47 & 3832914.67 & 772537.13 & 2586673.67 \\
0.3 & 412905.23 & 1916457.33 & 386268.57 & 1293336.83 \\
\hline
\end{tabular}

Source: own calculations.

\section{FINAL CONSIDERATIONS}

The necessity to evaluate public policies is an important issue to justify the amount of investment done in one matter. The analysis of cartel punishment effects is one way to verify how Competition Authorities are currently dealing with such crimes, considering that they are hard to detect and that investigations require financial and human resources expenses. The above analysis is a first insight to provide a view of how appropriate are the actual fine decisions done by the Brazilian Competition Authority.

Under Brazil's current competition law, cartel fines may vary from 0.1 to 20 percent of the companies' revenue from the year before the conduct began. The law also says fines should never be lower than the benefits companies received from the conduct when it is possible to calculate such benefits. However, these calculations are not straightforward; so, more time should be given to the evaluation of past condemned cartels fines considering the estimated damages. So far, this is the second study on cartel damages done in Brazil. Considering that the first study did not point to any deterrence effects of the applied policy, the estimations presented above do show that applied fines 
ended up considering it. The results here obtained may also help the Authority in the dosimeter fines calculations, which may have to consider not only the gravity of the conduct, but the industry characteristics. Industries with lower participants may be object of higher fines than colluding firms in a more oligopolistic environment.

In addition to competition policy debate, this paper also contributed to the fuel substitutability debate. Ethanol is perceived as a perfect substitute for gasoline. Subsidies for the promotion of this fuel as a more ecological friendly fuel might not achieve the wanted substitution effect if firms pricing strategy consider the ethanol equivalent fuel price in gasoline.

Future work, though, must consider a different specification of the demand choices for retailers, especially taking into account that neighbor's stores must have a greater impact on prices than distant ones. The demand characterization for both fuels (gasoline and ethanol) might allow a better assessment over the price cost margins through a structural simulation using the hypothesis that stations choices are differentiated goods.

\section{REFERENCES}

ALLAIN, M-L et al. Are cartel fines optimal? Theory and evidence from the European Union. International Review Of Law And Economics, [s.l.], v. 42, p. 38-47, jun. 2015. Elsevier BV. http://dx.doi.org/10.1016/j.irle.2014.12.004.

ANDERSON, S. T. The demand for ethanol as a gasoline substitute. Journal of Environmental Economics And Management, [s.1.], v. 63, n. 2, p. 151-168, mar. 2012. Elsevier BV. http:// dx.doi.org/10.1016/j.jeem.2011.08.002.

ANFAVEA - ASSOCIAÇÃO NACIONAL DOS FABRICANTES DE VEÍCULOS AUTOMOTORES. (Ed.). Anuário 2008. São Paulo: ANFAVEA, 2008. Available at: <http:// www.anfavea.com.br/anuario2008/capitulo2a.pdf>. Access on: Apr. 01, 2008.

BOLOTOVA, Y.; CONNOR, J. M.; MILLER, D. J. Factors influencing the magnitude of cartel overcharges: an empirical analysis of the U.S. market. Journal of Competition Law and Economics, [s.1.], v. 5, n. 2, p. 361-381, Aug. 28, 2008. Oxford University Press (OUP). http:// dx.doi.org/10.1093/joclec/nhn025.

BRASIL. CADE - CONSELHO ADMINISTRATIVO DE DEFESA ECONÔMICA. Processo 08012.011668-2007-30. Brasilia: CADE, 2010.

BRASIL. DEE - DEPARTAMENTO DE ESTUDOS ECONÔMICOS. (Ed.). Varejo de Gasolina. Brasilia: CADE, 2014.

CLARK, E. et al. (Ed.). Analysis of economic models for the calculation of damages. Brussels: Ashurst, 2004. 69 p.

CLARK, R.; HOUDE, J-F. Collusion with asymmetric retailers: evidence from a gasoline pricefixing case. American Economic Journal: Microeconomics, [s.1.], v. 5, n. 3, p. 97-123, Aug. 2013. American Economic Association. http://dx.doi.org/10.1257/mic.5.3.97. 
CLARK, R.; HOUDE, J-F. The effect of explicit communication on pricing: evidence from the collapse of a gasoline cartel. The Journal of Industrial Economics, [s.l.], v. 62, n. 2, p. 191-228, Jun. 2014. Wiley. http://dx.doi.org/10.1111/joie.12042.

CONNOR, J. M.; BOLOTOVA, Y. Cartel overcharges: survey and meta-analysis. International Journal of Industrial Organization, [s.l.], v. 24, n. 6, p. 1109-1137, Nov. 2006. Elsevier BV. http://dx.doi.org/10.1016/j.ijindorg.2006.04.003.

CONNOR, J. M. Cartels \& antitrust portrayed: private international cartels from 1990 to 2008. Ssrn Electronic Journal, [s.l.], p. 1-123, 2009. Elsevier BV. http://dx.doi.org/10.2139/ ssrn.1535131.

COVRIG, C. How sugar and ethanol impact each other? London: Platts Mcgraw Hill Financial, 2014. Color. Available at: <https://www.platts.com/IM.Platts.Content/ProductsServices/ ConferenceandEvents/2014/sc451/presentations/Claudiu-Covrig.pdf>. Access on: Apr. 17, 2019.

HOUDE, J-F. Spatial differentiation and vertical mergers in retail markets for gasoline. American Economic Review, [s.l.], v. 102, n. 5, p. 2147-2182, Aug. 2012. American Economic Association. http://dx.doi.org/10.1257/aer.102.5.2147.

HÜSCHELRATH, K.; WEIGAND, J. A framework to enforce anti-predation rules. World Competition, v. 2, p. 209-240, 2010.

LEVIN, L.; LEWIS, M. S.; WOLAK, F. A. High frequency evidence on the demand for gasoline. American Economic Journal: Economic Policy, [s.1.], v. 9, n. 3, p. 314-347, Aug. 2017. American Economic Association. http://dx.doi.org/10.1257/pol.20140093.

LUCINDA, C.; SEIXAS, R. Prevenção ótima de cartéis: o caso dos peróxidos no Brasil. Brasília: DEE/CADE, 2016. Available at: <http://www.cade.gov.br/acesso-a-informacao/ publicacoes-institucionais/dee-publicacoes-anexos/documento-de-trabalho-002-o-casodos-peroxidos-no-brasil.pdf>. Access on: May 15, 2016.

OECD - ORGANISATION FOR ECONOMIC CO-OPERATION AND DEVELOPMENT. Assessment of the impact of competition authorities' activities. Paris: OECD, 2013. (DAF/ COMP/WP2(2013)1). Available at: <http://www.oecd.org/officialdocuments/publicdisplayd ocumentpdf/?cote=DAF/COMP/WP2(2013)1\&docLanguage=En $>$. Access on: Apr. 17, 2019.

OECD - ORGANISATION FOR ECONOMIC CO-OPERATION AND DEVELOPMENT. Competition in road fuel. Paris: OECD, 2013. Available at: <https://www.oecd.org/ competition/CompetitionInRoadFuel.pdf>. Access on: Apr. 17, 2019.

RAGAZZO, C. E. J.; SILVA, R. M. Aspectos econômicos e jurídicos sobre cartéis na revenda de combustíveis: uma agenda para investigações. Brasilia: SEAE, 2006. (Documento de Trabalho SEAE no 40). Available at: <https://works.bepress.com/carlos_ragazzo/5/ download/>. Access on: Apr. 17, 2019.

SALVO, A.; HUSE, C Build it, but will they come? Evidence from consumer choice between gasoline and sugarcane ethanol. Journal of Environmental Economics And Management, [s.l.], v. 66, n. 2, p. 251-279, Sep. 2013. Elsevier BV. http://dx.doi.org/10.1016/j. jeem.2013.04.001.

VERBOVEN, F.; VAN DIJK, T. Cartel damages claims and the passing-on defense. The Journal of Industrial Economics, [s.l.], v. 57, n. 3, p. 457-491, Sep. 2009. Wiley. http://dx.doi. $\operatorname{org} / 10.1111 /$ j.1467-6451.2009.00390.x. 


\section{APPENDIX}

\section{List of Condemned Fuel Retailers and Managers}

\begin{tabular}{|c|c|}
\hline & Fines $(\mathrm{R} \$)$ \\
\hline 1. AVN Comércio de Combustíveis Ltda. (Auto Posto Bonanza) & 610314.46 \\
\hline 2. Mazzarelo\& Cia Ltda. (Auto Posto Flamboyant) & 851280.00 \\
\hline 3. OílPetro Brasileira de Petróleo Ltda. & 851280.00 \\
\hline 4. DGJR Comércio de Combustíveis Ltda. (Posto Versailles e Posto Versailles II) & 851280.00 \\
\hline S. J Ramalho \& Cia Ltda. (Auto Posto Versailles III) & 851280.00 \\
\hline 6. Auto Posto 10 de Dezembro Ltda. & 851280.00 \\
\hline 7. Posto_Novo_Oriente Ltda. & 851280.00 \\
\hline 8. C.O. Bolognesi \& Bolognesi Ltda. (Posto Tropical) & 851280.00 \\
\hline 9. Auto Posto Paiaguás_Ltda. & 487134.86 \\
\hline 10. Etiel Comércio de Combustíveis Ltda. (Posto Paizão) & 744870.00 \\
\hline 11. Auto Posto Brasília de Londrina Ltda (Posto Meninão) & 744870.00 \\
\hline 12. Auto Posto Exposição Ltda. & 744870.00 \\
\hline 1. Mauro Cesar Guarda & 255384.00 \\
\hline 2. Jonatas Cerqueira Guarda & 127692.00 \\
\hline 3. Claudir_Osmir Bolognesi & 255384.00 \\
\hline 4. Itauby Netto José Ramalho & 255384.00 \\
\hline 5. Djalma Eugênio Guarda & 346931.17 \\
\hline 6. Djalm aEugênio Guarda Júnior & 79340.88 \\
\hline 7. Sergio Goes_de_Oliveira & 290499.30 \\
\hline 8. Edson Fernandes Gimenes & 63327.53 \\
\hline TOTAL & 10964962.20 \\
\hline
\end{tabular}

Source. CADE Administrative Process 08012.011588/2007-30 